MATEC Web of Conferences 37, 01029 (2015)

DOI: $10.1051 /$ matecconf/20153701029

(C) Owned by the authors, published by EDP Sciences, 2015

\title{
CHANGE IN IGNITION CHARACTERISTICS OF COMPOSITE LIQUID FUEL DROPLET WHILE VARYING THE COMBUSTIBLE LIQUID CONTENT
}

\author{
A. G. Kosintsev" ${ }^{1}$, V. V. Medvedev ${ }^{1}$, P. A. Strizhak ${ }^{1, a}$ \\ ${ }^{1}$ National Research Tomsk Polytechnic University, 634050 Tomsk, Russia
}

\begin{abstract}
The features of heat and ignition of composite liquid fuel droplets in a heated (temperatures were600-900 K) oxidant were investigated to develop modern recycling technologies of processing waste of coal, petroleum products, liquid fuels and combustible liquids. Compositions based on tailings of bituminous coal, used turbine and motor oils were considered. Ignition delay times of composite fuel droplets were defined. The influence scale of mass fraction of combustible liquid on droplet heat and ignition characteristics were identified.
\end{abstract}

\section{Introduction}

In recent years, it was made efforts to use the coal-water suspensions as fuel at power engineering facilities [1,2] instead of traditional solid fuel [3, 4]. This can be explained by several advantages of such compositions in comparison with coal dust: explosive safety, relatively low concentration of injurious substances (sulfur and nitrogen oxides) in gas-like combustion products, the possibility of utilization of solid and combustible waste. The results of investigations $[5,6]$ allowed establishing that one of the main problems preventing the widespread use of coal-water suspensions in power plants is low degree of combustibility and heat input during burning.

One possible approach for solving this problem is addition of liquid combustible components in coal-water suspensions [7-9]. Such mixtures are usually referred to as composite liquid fuels (CLF). It is possible to use petroleum wastes as flammable liquid, e.g. used motor, turbine, transformer and other oils. The variability of timing characteristics of CLF ignition and combustion due to varying the admixture concentration of used oils is of interest to study.

The aim of the present investigations is determination of influence of flammable liquid in a CLF on characteristics of single droplet ignition.

\section{Page Experimental setup and procedure}

Figure 1 illustrates an appearance of the experimental setup for investigation of processes occurring at heating the single droplet of CLF by hot air.

\footnotetext{
${ }^{a}$ Corresponding author: pavelspa@tpu.ru
} 


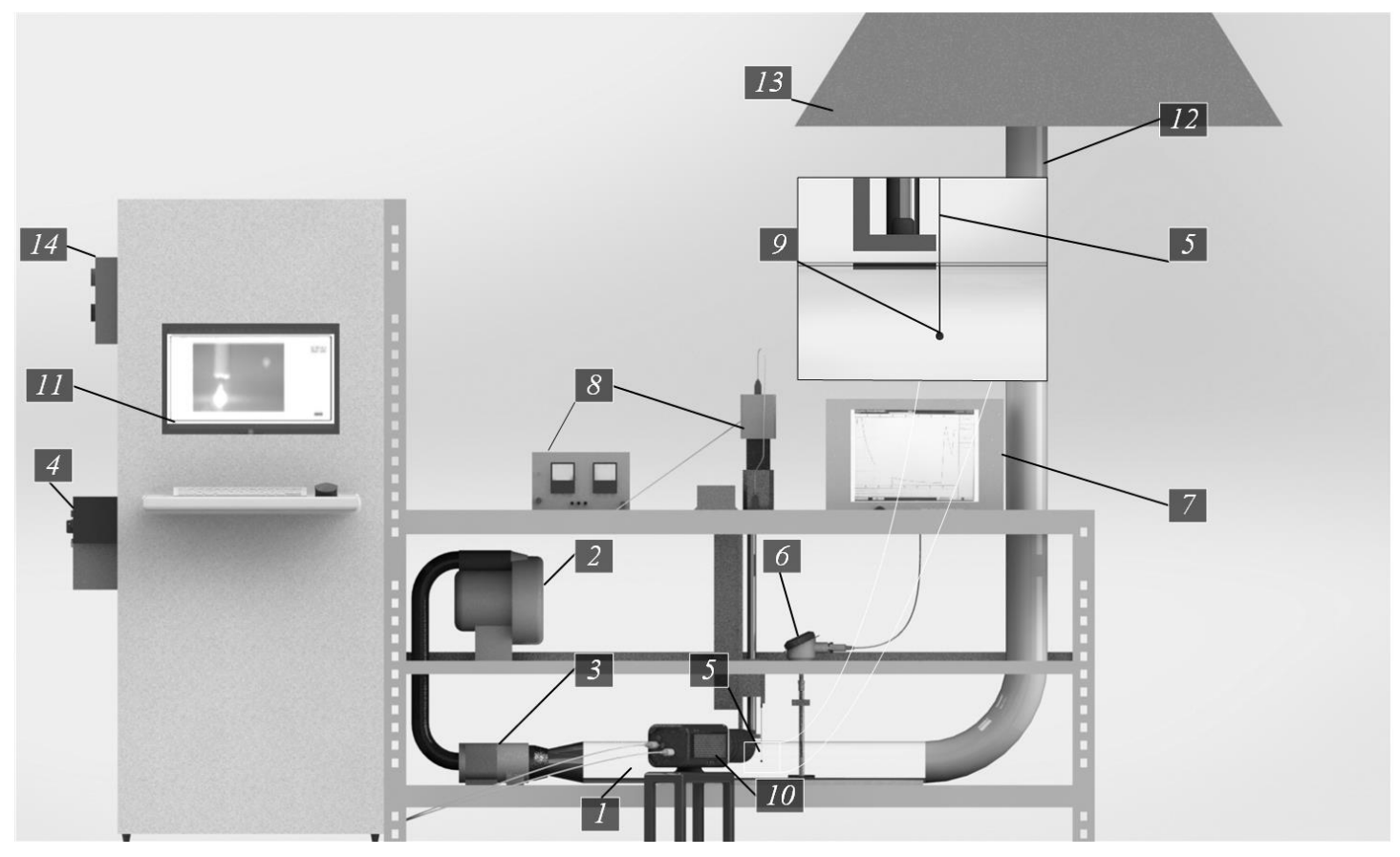

Fig. 1. Scheme of experimental setup: 1 - hollow glass cylinder; 2 - blower; 3 - air heater; 4 - remote control; 5 - ceramic rode; 6 - thermocouple; 7 - registrar; 8 - coordinate mechanism; 9 - droplet; 10 - high-speed video camera; 11 - computer; 12 - vent tube; 13 - exhaust ventilation; 14 - remote control of exhaust ventilation

Heated air flow was formed in a quartz glass cylinder 1 . Parameters of heat source (air temperature $T_{\mathrm{g}}=400-600{ }^{\circ} \mathrm{C}$, flow velocity $V_{\mathrm{g}}=1-5 \mathrm{~m} / \mathrm{s}$ ) were varied by a blower 2 and air heater 3 with remote control 4. We monitored air temperature by thermocouple 6 (type $\mathrm{K}$ ) fixed in one of three technological holes made in a cylinder 1 . The flow velocity was controlled by anemometer UnionTest AN110.

To inject droplet in a cylinder 1 , we applied a coordinate mechanism 8 which provides a transfer of droplet 9 , hanging on a contact point of ceramic shank 5 , though a technological hole from the periphery to center of channel 1 .

Temperature $\left(T_{g}\right)$, air movement velocity $\left(V_{g}\right)$, droplet radius $\left(R_{d}\right)$, ignition delay time $\left(\tau_{d}\right)$ was recorded and calculated by recording instrument 7 , high-speed camera 10 and computer 11 with special software Tema Automotive. Initial sizes of droplets varied within the range of $0.5-1.5 \mathrm{~mm}$. A mixture of air flow and combustion products of CLF was eliminated from cylinder 1 by vent tube 12 and exhaust ventilation 13 which is operated by remote control 14 .

We investigated two groups of compositions. Two groups introduce compositions based on filter cake of bituminous coal (the enrichment factory "Severnaya" of the Kemerovo region, Russia) with addition of used motor or turbine oil. Mass concentration of oils varied within the range of $0-15 \%$. The filter cake is a waste of coal dressing and represents a mixture of coal dust with particle sizes about $80 \mu \mathrm{m}$ and water with mass fractions about $56 \%$ and $44 \%$, correspondingly. The thermal effect of such mixture combustion is $14.04 \mathrm{MJ} / \mathrm{kg}$. Tables 1 and 2 present the results of technical and elemental analysis of filter cake (dry). The main characteristics of the motor and turbine oils are in Table 3.

Table 1. The results of the technical analysis of filter cake.

\begin{tabular}{|c|c|c|c|c|}
\hline Sample & $W^{\mathrm{a}}, \%$ & $A^{\mathrm{d}}, \%$ & $V^{\text {daf }}, \%$ & $Q_{\mathrm{s}}^{\mathrm{a}}, \mathrm{MJ} / \mathrm{kg}$ \\
\hline Filter cake (dry) of bituminous coal & - & 26.46 & 23.08 & 24.83 \\
\hline
\end{tabular}


Table 2. The results of the elemental analysis of filter cake.

\begin{tabular}{|c|c|c|c|c|c|}
\hline Sample & $\mathrm{C}^{\text {daf }}, \%$ & $\mathrm{H}^{\text {daf }}, \%$ & $\mathrm{~N}^{\text {daf }}, \%$ & $\mathrm{~S}^{\text {daf }}, \%$ & $\mathrm{O}^{\text {daf }}, \%$ \\
\hline Filter cake (dry) of bituminous coal & 87.20 & 5.090 & 2.05 & 1.022 & 4.46 \\
\hline
\end{tabular}

Table 3. The main characteristics of liquid fuel components.

\begin{tabular}{|c|c|c|c|c|c|c|}
\hline Sample & $\begin{array}{c}\text { Density at 293 } \\
\mathrm{K}, \mathrm{kg} / \mathrm{m}^{3}\end{array}$ & Humidity, \% & Ash, \% & $\begin{array}{c}\text { Flash } \\
\text { temperature, } \mathrm{K}\end{array}$ & $\begin{array}{c}\text { Ignition } \\
\text { temperature, } \mathrm{K}\end{array}$ & $\begin{array}{c}\text { Heat of combustion, } \\
\mathrm{MJ} / \mathrm{kg}\end{array}$ \\
\hline Engine oil & 871 & 0.28 & 0.78 & 405 & 491 & 44 \\
\hline Turbine oil & 868 & - & 0.03 & 448 & 466 & 44.99 \\
\hline
\end{tabular}

\section{Results and discussion}

Figure 2 shows typical frames at combustion initiation of CLF droplet (filter cake $90 \%+$ used motor oil $10 \%)$.

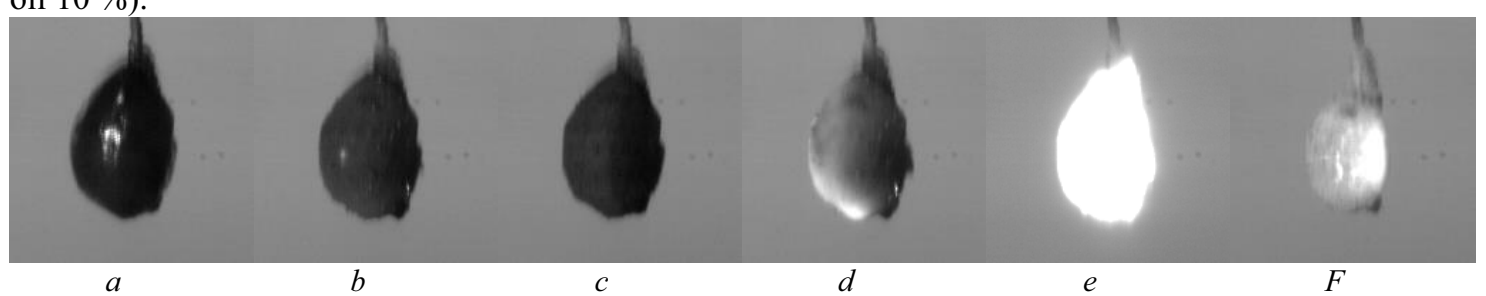

Fig. 2. Typical frames of ignition stages for CLF droplet at $R_{d} \approx 1 \mathrm{~mm}, T_{g} \approx 600{ }^{\circ} \mathrm{C}, V_{g} \approx 5 \mathrm{~m} / \mathrm{s}: a$ - heating; $b-$ moisture evaporation; $c$ - thermal decomposition and yield of volatiles; $d$ - carbon ignition; $e$ - carbon combustion; $f$-carbon burning out

Primary stages (Fig. 2, $a-c$ ) are the most longtime. This is due to heat inertia of the droplet boundary layer, energy output for liquid component evaporation and coal thermal decomposition, mostly. These endothermal phase transformations play the determining role. Moreover, the duration of stages is changed with increasing the liquid combustible component concentration in CLF composition as indicated by a reduction of values of ignition delay time (Table 4).

Table 4. Ignition delay time $\left(\tau_{d}, \mathrm{~s}\right)$ of CLF droplet

\begin{tabular}{|l|c|c|c|c|c|c|c|c|}
\hline & \multicolumn{3}{|c|}{ Filter cake + turbine oil waste } & \multicolumn{3}{c|}{ Filter cake + engine oil waste } \\
\hline $\begin{array}{l}\text { Mass fraction of oil in CLF } \\
\text { composition }\end{array}$ & $0 \%$ & $5 \%$ & $10 \%$ & $15 \%$ & $0 \%$ & $5 \%$ & $10 \%$ & $15 \%$ \\
\hline Droplet $0.5 \mathrm{~mm}$ & 5.49 & 4.84 & 4.62 & 4.45 & 5.49 & 5.61 & 5.50 & 5.24 \\
\hline Droplet $1 \mathrm{~mm}$ & 14.76 & 10.52 & 9.25 & 8.94 & 14.76 & 10.58 & 10.43 & 9.69 \\
\hline Droplet $1.5 \mathrm{~mm}$ & 22.03 & 15.25 & 15.15 & 13.27 & 22.03 & 16.04 & 15.94 & 14.35 \\
\hline
\end{tabular}

Close values of heat inertia stages of CLF droplets with various content of combustion liquid can be noted. But the stages of thermal decomposition differ significantly due to low flaming temperature of combustible liquid vapors in comparison with volatile ignition. This, particularly, can explain differences of periods $\tau_{d}$ marked in Fig. 3 for droplets of considered CLF compositions. 


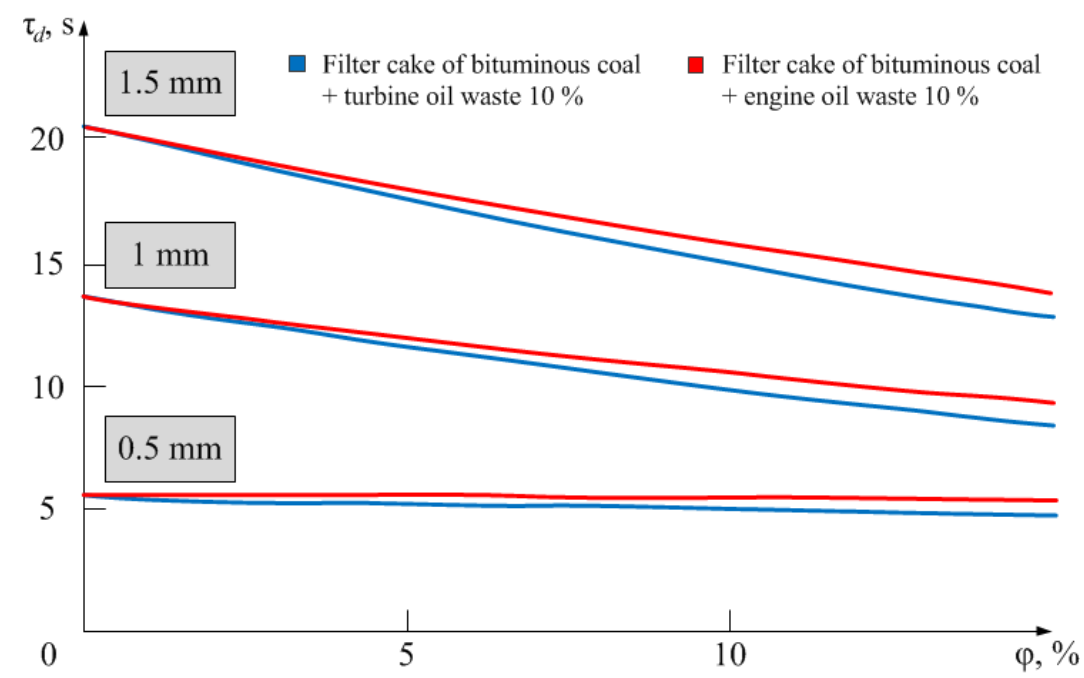

Fig. 3. Ignition delay times of CLF droplets according to mass fraction of combustible liquid

It is obvious (Fig. 3) that ignition delay times for droplets of sizes $0.5-1.5 \mathrm{~mm}$ reduce by $20-40 \%$ with increasing the mass fraction of combustible liquid in CLF composition to $15 \%$. This effect is characteristic for droplets relative to big size. For droplets of less size, the change of $\tau_{d}$ does not exceed $10 \%$. It is also should be noted the long duration of induction period for CLF droplets based on used motor oil in comparison with CLF composition based on used turbine oil under similar conditions (in particular, $\varphi=$ const). The obtained result is explained by difference of the main characteristics (Table 3) of liquid combustible components.

\section{Conclusion}

The conducted experiments allowed establishing the stable conditions of droplet ignition of considered CLF compositions at $0.5<R_{d}<1.5 \mathrm{~mm}, T_{g}>850 \mathrm{~K}, V_{g}>5 \mathrm{~m} / \mathrm{s}$. These conditions correspond to modern and promising power plants. The obtained results can be used to develop a general ignition theory of CLF produced on the base of waste of coal processing and used combustible liquids and petroleum products.

The study was supported by the Russian Science Foundation (project No. 15-19-10003).

\section{References}

1. R. Chen, M. Wilson, Y. K. Leong, P. Bryant, H. Yang, D. K. Zhang, Fuel 90, 1689 (2011).

2. W. Gajewski, A. Kijo-Kleczkowska, J. Leszczynski, Fuel 88, 221 (2009).

3. D. O. Glushkov, G. V. Kuznetsov, P. A. Strizhak, Solid Fuel Chemistry 49 (2), 73 (2015).

4. D. O. Glushkov, P. A. Strizhak, O. V. Vysokomornaya, Thermal Science 19 (1), 285 (2015).

5. T. Takeshita, K. Yamaji, Environmental Economics and Policy Studies 8, 55 (2014).

6. N. Lior, Energy 33, 842 (2008).

7. S. Belošević, I. Tomanović, V. Beljanski, D. Tucaković, T. Živanović, Applied Thermal Engineering 74, 102 (2015).

8. G. S. Khodakov, E. G. Gorlov, G. S. Golovin, Solid Fuel Chem. 40, 19 (2006).

9. D. Yu. Bukhonov, V. V. Morozov, Thermal Engineering 50, 1039 (2003). 